Open Journal System

Volume 1 no 12020

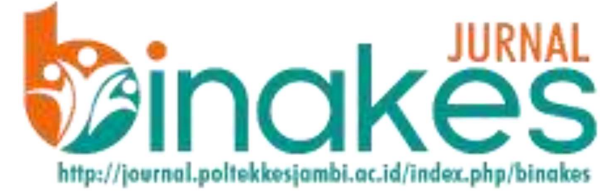

\title{
UPAYA PENCEGAHAN PENYAKIT KARDIOVASKULER MELALUI IDENTIFIKASI RESIKO DAN LATIHAN FISIK PADA WANITA
}

Netha Damayantie ${ }^{1}$, Rusmimpong ${ }^{1}$

${ }^{1}$ Jurusan Keperawatan Poltekkes Kemenkes Jambi

\begin{abstract}
KONTAK PENULIS
\section{ABSTRAK}

nethafauzi@gmail.com

Latar Belakang: Kesadaran akan pentingnya kesehatan jantung pada kaum perempuan masih rendah, masih adanya stigma bahwa kesehatan kaum laki-laki lebih penting, masih banyak profesional medis yang beranggapan penyakit

DOI: kardiovaskular (PKV) adalah penyakit kaum laki-laki. Pada perempuan gejalanya

https://doi.org/10.35910/binake s.v1i1.369 memang tidak khas, sehingga seringkali terlewatkan.

Metode:Mitra kegiatan pengabdian masyarakat ini adalah 58 wanita di Kelurahan Simpang Tiga Sipin. Kegiatan dilakukan dengan pendekatan partisipatif dan sosial, berupa penyuluhan kesehatan tentang faktor resiko penyakit kardiovaskuler pada wanita, demonstrasi pengisian Framingham Risk Score (FRS) dan relaksasi otot progresif.
\end{abstract}

Kata Kunci:

Hasil: Adanya peningkatan pengetahuan dari 33\% menjadi $66 \%$ pengetahuan tinggi. Pada saat pengisian FRS hanya 8 orang yang mampu mengisi secara lengkap.

penyakit kardiovaskuler; latihan Peserta antusias melakukan latihan relaksasi otot progresif.

fisik; wanita

Kesimpulan: Terjadi peningkatan pengetahuan mengenai upaya pencegahan penyakit kardiovaskule melalui identifikasi rasio dan latihan fisik pada wanita.

\begin{abstract}
Background: Awareness of the importance of heart health in women is still low, there is still a stigma that men's health is more important. There are still many medical professionals who think cardiovascular disease (CVD) is a disease of men. The symptoms in woman are not typical, so they are often overlooked.
\end{abstract}

Methods: Partners of this community service activity are 58 women in Simpang Tiga Sipin $V$ illage. The activity was carried out with a participatory and social approach, in the form of health education about risk factors for cardiovascular disease in women, demonstrations on filling out the Framingham Risk Score (FRS) and progressive muscle relaxation.

Result: There is an increase in knowledge from 33\% to 66\% of high knowledge. At the time of Keywords: filling the FRS only 8 people were able to fill it completely. Participants were enthusiastic about doing progressive muscle relaxation exercises. 


\section{PENDAHULUAN}

Ada berbagai macam penyakit kardiovaskuler, namun penyakit kardiovaskuler yang umumnya paling banyak dialami masyarakat dunia adalah penyakit jantung koroner. Hal ini dikarenakan penyakit jantung koroner banyak menyerang usia produktif dan dapat menyebabkan kematian mendadak (Nadianto F, 2018). Laporan dari negara-negara maju seperti Amerika, Eropa, dan Australia menyatakan bahwa, peringkat pertama penyebab kematian pada perempuan usia 65 tahun ke atas adalah penyakit jantung, diikuti oleh kanker dan stroke. Hal serupa juga akan terjadi di Indonesia, yang ikut berkontribusi atas hampir sembilan juta kematian perempuan dunia setiap tahun akibat penyakit jantung dan pembuluh darah (kardiovaskular). Penyakit kardiovaskuler adalah penyakit yang disebabkan gangguan fungsi jantung dan pembuluh darah, seperti penyakit jantung koroner, penyakit gagal jantung atau payah jantung, hipertensi dan stroke (Kemkes, 2014). Penyakit jantung coroner (PJK) merupakan kontributor kematian terbesar, padahal penyakit ini sebenarnya dapat dicegah seperti halnya mencegah stroke(Inaheart, 2018)

Di Indonesia, Riset Kesehatan Dasar 2013 menunjukkan prevalensi penyakit jantung koroner 1,5\%, meningkat seiring dengan bertambahnya umur, tertinggi pada kelompok umur 65-74 tahun yaitu 2,0\% dan $3,6 \%$, menurun sedikit pada kelompok umur $\geq 75$ tahun (Kemenkes, 2014). Riset Kesehatan Dasar 2018 juga menunjukkan prevalensi penyakit jantung sebesar 1,5\% (Kemenkes, 2019). Faktor risiko penyakit kardiovaskular ada yang tidak dapat dimodifikasi dan ada yang dapat dimodifi kasi. Faktor risiko yang tidak dapat dimodifi kasi, antara lain: usia, jenis kelamin, riwayat penyakit keluarga, dan ras. Sedangkan, faktor risiko penyakit kardiovaskular yang dapat dimodifikasi, antara lain: hipertensi, profi 1 lipid yang buruk, merokok, kurangnya aktivitas fi sik, obesitas, diabetes melitus, konsumsi makanan berlemak, dan konsumsi alkohol berlebih. Faktor risiko penyakit kardiovaskular bersifat kumulatif, artinya semakin banyak faktor risiko yang dimiliki, maka risiko untuk menderita penyakit kardiovaskular semakin tinggi (Setiadi, 2013).

Upaya pencegahan terutama dilakukan pada kelompok berisiko di komunitas. Penentuan kelompok berisiko dapat dilakukan dengan berbagai macam instruman. Framingham Risk Score (FRS) 10 years merupakan salah satu alat yang yang paling sensitif untuk menentukan faktor risiko penyakit kardiovaskuler dalam 10 tahun yang akan datang melalui pengkategorian risiko; mulai dari risiko sangat rendah, risiko rendah, risiko sedang sampai risiko tinggi (Scottish Intercollegiate Guidelines Network, 2007). Framingham Risk Score (FRS), digunakan untuk meramalkan terjadinya kejadian kardiovaskular dalam 10 tahun mendatang, akan tetapi, menurut studi yang dilakukan oleh Nurwidyaningtyas (2013) alat ukur ini belum umum digunakan di masyarakat. Hal ini dapat terjadi karena masyarakat kurang memahami bahwa kelompok risiko tinggi penyakit kardiovaskuler dapat diidentifikasi dengan cara yang dapat dilakukan baik oleh kader, warga atau justru keluarga inti sendiri. Deteksi dini kelompok risiko ini dapat menahan peningkatan prevalensi penyakit kardiovaskuler.

Persepsi wanita terhadap penyakit jantung sangat mempengaruhi proses pengambilan keputusan kesehatan. perempuan lebih banyak terkena penyakit jantung pada usia menopause atau usia 42-50 tahun. Hal ini diduga karena adanya perubahan hormon estrogen pada wanita setelah menopause. Namun, faktor risiko penyakit jantung tidak tunggal. Tiga faktor risiko dominan penyakit kardiovaskular pada perempuan yaitu usia, hipertensi, dan kolesterol yang tinggi (Rosjidi, 2014). Salah satu bentuk upaya pencegahan penyakit kardiovaskuler dapat dilakukan dengan pendekatan keluarga. Fungsi utama keluarga salah satu diantaranya adalah fungsi perawatan keluarga, dimana keluarga melaksanakan tugas perawatan kesehatan yang bersifat preventif dan secara bersama-sama merawat anggota keluarga yang sakit. Kesanggupan keluarga melaksanakan perawatan atau pemeliharaan kesehatan dapat dilihat dari tugas kesehatan keluarga yang dilaksanakan (Mubarak, Chayatin, \& Santoso, 2010). 
Pengabdian masyarakat ini menindaklanjuti hasil pengabdian masyarakat pada bulan Juli 2019, dimana diketahui dari 59 ibu-ibu yang dilakukan pengukuran tekanan darah dan kholesterol, $41 \%$ memiliki Tekanan darah $\geq 140 \mathrm{mmhg}$ dan $47 \%$ kadar kolesterol darah $\geq 200 \mathrm{mg} / \mathrm{dl}$. Hasil ini menunjukkan adanya faktor-faktor resiko penyakit kardiovaskuler pada ibu-ibu di RT 05, 06, 09 dan 37 Kelurahan Simpang Tiga Sipin. Para tenaga kesehatan dapat memperkirakan dan mengkomunikasikan kepada pasien/ klien strategi yang dapat diambil dengan melakukan estimasi risiko pada seorang perempuan untuk memperbaiki resiko penyakit kardiovaskuler

\section{METODE}

Dalam rangka justifikasi permasalahan bersama mitra maka pendekatan yang digunakan adalah pendekatan partisipatif dan sosial. Mitra dijadikan subjek kegiatan dan melibatkannya secara nyata dalam penyelesaian masalah. Pendekatan ini dipilih agar mitra menyadari dan tumbuh kesadaran bahwa masalah yang dirumuskan adalah masalah mereka yang harus diselesaikan mereka sendiri dengan bantuan dari perguruan tinggi (Tim PPM), diharapkan akan tumbuh kemandirian mitra untuk menghadapi dan memecahkan permasalahan yang dihadapi jika menemukan masalah yang sama pada masa yang akan datang. Pelaksanaan upaya pencegahan penyakit kardiovaskuler melalui identifikasi resiko dan latihan fisik pada wanita di wilayah Kelurahan Simpang Tiga Sipin Kota Jambi, dilakukan dengan metode penyuluhan kesehatan tentang penyakit kardiovaskuler, faktor resiko penyakit kardiovaskuler pada wanita, simulasi dan demonstrasi pengisian Framingham Risk Score (FRS) untuk mengidentifikasi resiko hipertensi dalam 10 tahun ke depan dan relaksasi otot progresif untuk melatih relaksasi otot, mengatasi kelelahan, kecemasan dan memperbaiki tekanan darah.

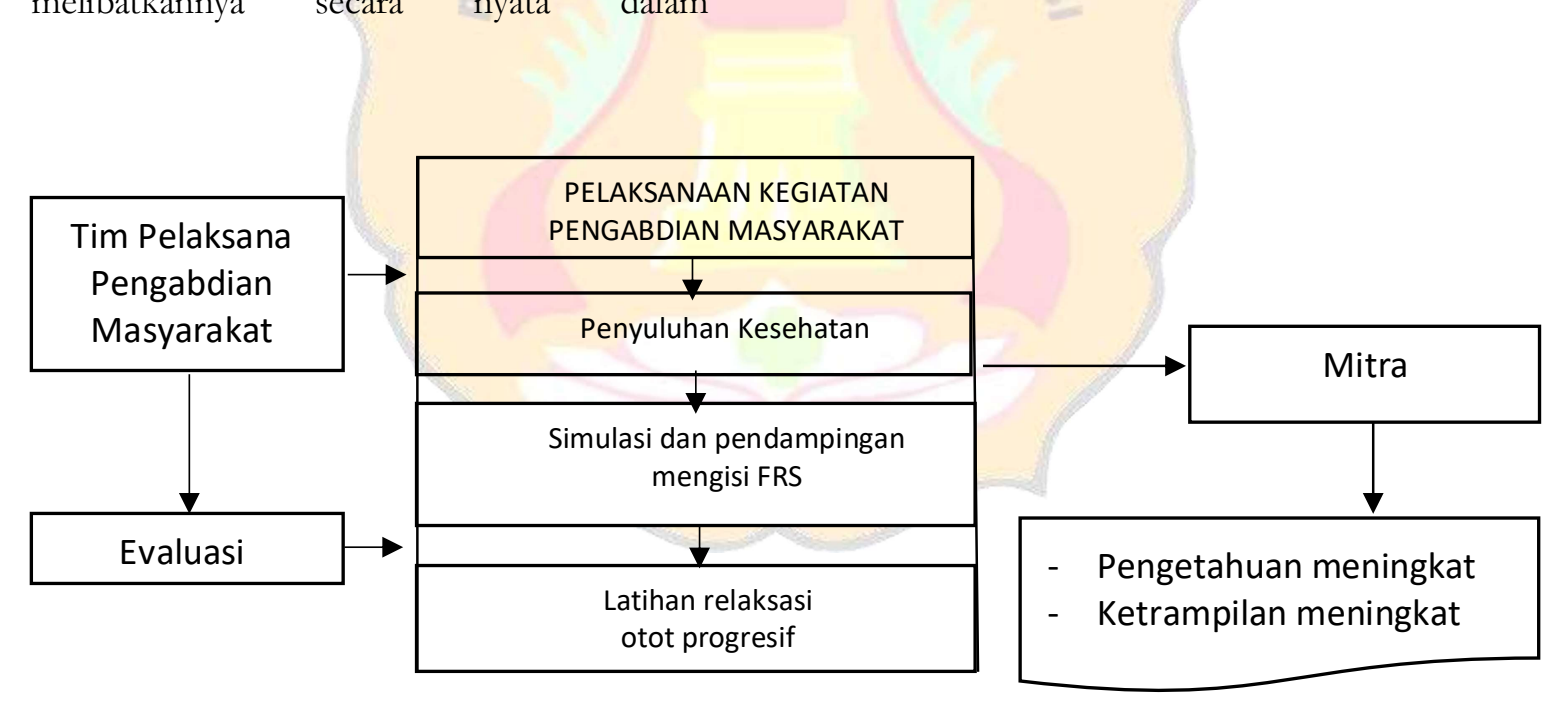

Gambar 1. Skema Pelaksanaan Pengabdian Masyarakat

\section{HASIL DAN PEMBAHASAN}

Kegiatan diawali dengan survey awal pada tanggal 28 September 2019 untuk menentukan lokasi pengabdian masyarakat, mengidentifikasi permasalahan dan kesesuaian topik pengabdian masyarakat dengan kebutuhan masyarakat. Izin pelaksanaan kegiatan dilakukan dengan memberikan surat izin pengabdian masyarakat N0. PP.07.01/3.4/722/2019 kepada Lurah Simpang Tiga Sipin. Dilanjutkan dengan survey awal pada lokasi yang telah ditentukan yaitu RT 05, 06, 09 dan 37 Kelurahan Simpang Tiga Sipin melalui koordinasi dengan ketua RT 06 meliputi sasaran, tempat dan tahapan 
pelaksanaan kegiatan. Mempersiapkan mahasiswa untuk membantu pelaksanaan kegiatan. Mahasiswa yang mengikuti kegiatan sebanyak 3 orang yaitu mahasiswa Sarjana Terapan Keperawataan Jurusan Keperawatan Poltekkes Kemenkes Jambi.

Pada tanggal 26 Oktober 2019 dilaksanakan kegiatan penyuluhan dalam rangka meningkatkan pengetahuan tentang penyakit kardiovaskuler, faktor resiko penyakit kardiovaskuler. Kegiatan diawali pemeriksaan tekanan darah. Selanjutnya dilakukan penyuluhan kesehatan tentang penyakit kardiovaskuler, upaya pencegahan penyakit kardiovaskuler dan dilakukan simulasi pengisian Framingham Risk Score (FRS) 10 years. Selama pengisian FRS peserta didampingi oleh dosen dan mahasiswa. Kegiatan dilanjutkan dengan simulasi dan latihan relaksasi otot progresif untuk. Mitra diperlihatkan video latihan relaksasi otot progresif, kemudian mendemonstrasikan kembali dengan didampingi mahasiswa

Pada saat penyuluhan dilakukan eksplorasi pengetahuan peserta tentang penyakit jantung koroner, faktor resiko dan upaya pencegahan penyakit janung koroner. Selama penyuluhan peserta memberikan pertanyaan, antara lain : bagaimana cara menjaga agar tekanan darah stabil, bagaimana cara mencegah penyakit kardiovaskuler pada anggota keluarga sementara di keluarga ada riwayat hipertensi. Kegiatan pengabdian masyarakat dilaksanakan dengan sasaran wanita karena saat ini terdapat kesalahan persepsi bahwa penyakit kardiovaskular bukan merupakan masalah nyata pada perempuan. Saat ini penyakit kanker payudara, kanker mulut rahim merupakan penyakit yang paling ditakuti kaum perempuan. Hal ini berbeda dengan fakta yang ada menurut para ahli membuat prediksi satu diantara dua perempuan mati (1:2) karena penyakit kardiovaskular (penyakit jantung koroner dan stroke) dibanding satu diantara duapuluh lima kaum perempuan yang mati (1:25) karena penyakit kanker payudara.

Persepsi yang salah tentang penyakit kardiovaskular berpengaruh terhadap ketidakwaspadaan terhadap serangan penyakit kardiovaskular. Faktor resiko penyakit kardiovaskuler adalah hiperlidemi, merokok, dan hipertensi, Selain menjaga kadar kolesterol dalam darah dalam batas normal,perlu memperhatikan indek massa tubuh atau berat badan. Seiring dengan pertambahan usia juga berakibat mudah bertambahnya lemak tubuh. Kegemukan menyebabkan turunnya kadar kolesterol High Density Lipoprotein (HDL) dan naiknya trigliserida. Resiko PJK lebih tinggi pada individu dengan konsentrasi kolesterol HDLrendah

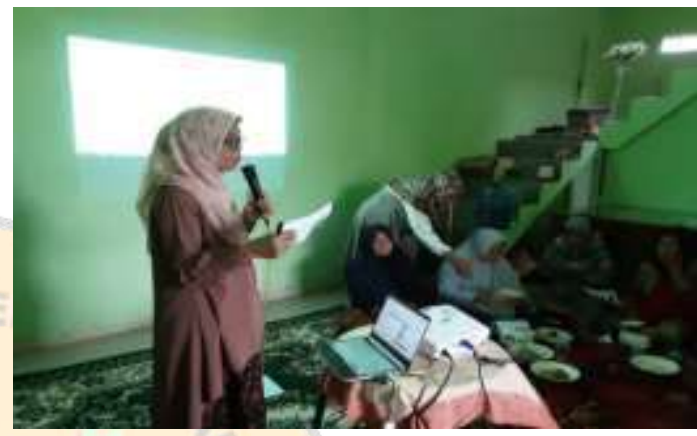

Gambar 2. Kegiatan Penyuluhan kepada Ibu ibu RT 05, 06, 09 dan 37 Kelurahan Simpang Tiga Sipin.

Salah satu upaya untuk mencegah resiko penyakit kardiovaskuler (PKV) adalah dengan memahami dan mampu menidentifikasi resiko menderita penyakit jantung. Salah satunya dengan menggunakan Framingham Risk Score (FRS) 10 years. FRS mengidentifikasi reiko berdasarkan usia, kolesterol HDL, total kolesterol, tekanan darah sistolik dan riwayat merokok. Berdasarkan total poin disetarakan dengan persentasi sehingga akan diketahui seseorang beresiko berapa persen untuk menderita penyakit kardiovaskuler dalam 10 tahun mendatang. Pada saat mendampingi peserta mengisi FRS tidak semua peserta pernah memeriksakan kolesterol HDL. Yang mengetahui nilai kolesterol HDL hanya 8 orang yang pernah memeriksa. Sedangkan nilai kolesterol didapat saat pengukuran di bulan Juli pada saat pengabdian masyarakat semester genap tahun 2019, sehingga tidak semua peserta mampu melengkapi form FRS. Para ibu menyatakan sangat senang mendapatkan informasi tentang penyakit kardiovaskuler dan diajarkan cara mengidentifikasi resikonya menggunakan 
Framingham Risk Score (FRS) 10 years. Menurut Inaheart, (2015) Dengan FRS seseorang akan diklasifikasikan sebagai risiko tinggi, risiko menengah dan risiko rendah untuk terjadinya penyakit kardiovaskuler. Dengan melakukan estimasi risiko pada seorang perempuan, maka para tenaga kesehatan dapat memperkirakan dan mengkomunikasikan kepada pasien/ klien strategi yang dapat diambil untuk memperbaiki angka risiko tersebut. Penekanan sebaiknya diberikan kepada modifikasi gaya hidup (olahraga, pola hidup sehat dan berhenti merokok) yang memiliki peran besar dalam memperbaiki risiko terjadinya penyakit kardiovaskuler

Kegiatan latihan relaksasi otot progresif diawali dengan memutarkan video tentang relaksasi otot progresif yaitu metode relaksasi dua proses yaitu menegangkan an merelaksasi otot tubu, kegiatan ini mudah dipelajari. Manfaat dari latihan ini adalah menurunkan tegangan fisik, menurunkan nadi dan tekanan darah. Peserta menunjukkan antusias melakukan setiap gerakan yang diajarkan walaupun belum sepenuhnya melakukan geraan dengan benar.

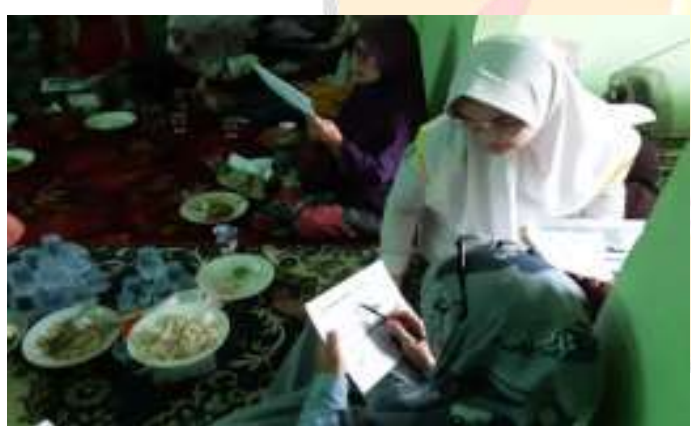

Gambar 3. Pendampingan Pengisian Framingham Risk Score (FRS) 10 years

Undang-undang Nomor 12 Tahun 2012 tentang Pendidikan Tinggi Pasal 47 menegaskan bahwa pengabdian kepada masyarakat merupakan kegiatan Civitas Akademika dalam mengamalkan dan membudayakan Ilmu Pengetahuan dan Teknologi untuk memajukan kesejahteraan umum dan mencerdaskan kehidupan bangsa; (2) Pengabdian kepada masyarakat sebagaimana dimaksud pada ayat (1) dilakukan dalam berbagai bentuk kegiatan sesuai dengan budaya akademik, keahlian, dan/atau otonomi keilmuan civitas akademika serta kondisi sosial budaya masyarakat; (3) Hasil pengabdian kepada masyarakat digunakan sebagai proses pengembangan ilmu pengetahuan dan teknologi, pengayaan sumber belajar, dan/atau untuk pembelajaran dan pematangan civitas akademika. Pengabdian kepada masyarakat yang dilakukan oleh dosen Kelurahan Simpang Tiga Sipin Kota Jambi berupa optimalisasi tugas perawatan kesehatan oleh keluarga sebagai upaya meningkatkan status kesehatan penderita hipertensi di Kelurahan Simpang Tiga Sipin Kecamatan Kotabaru, dimana dosen bekerjasama dengan pihak kelurahan melakukan upaya promotifeducative dengan melibatkan berbagai institusi terkait, kampus dan sekolah melalui kegiatan pengabdian masyarakat dosen Jurusan Keperawatan Poltekkes Jambi.

Setelah dilakukan pretest dan post test terjadi peningkatan pengetahuan peserta menjadi lebih baik dari 19 orang (33\%) pengetahuan tinggi menjadi 45 orang (77\%) pengetahuan tinggi. Hasil ini sejalan dengan pendapat Notoatmodjo (2010) pengetahuan (knowledge) adalah hasil penginderaan manusia, atau hasil tahu seseorang terhadap objek melalui indera yang dimilikinya (mata, hidung, telinga, dan sebagainya). Dengan sendirinya, pada waktu penginderaan sampai menghasilkan pengetahuan tersebut sangat dipengaruhi oleh intensitas perhatian dan persepsi terhadap objek intervensi.

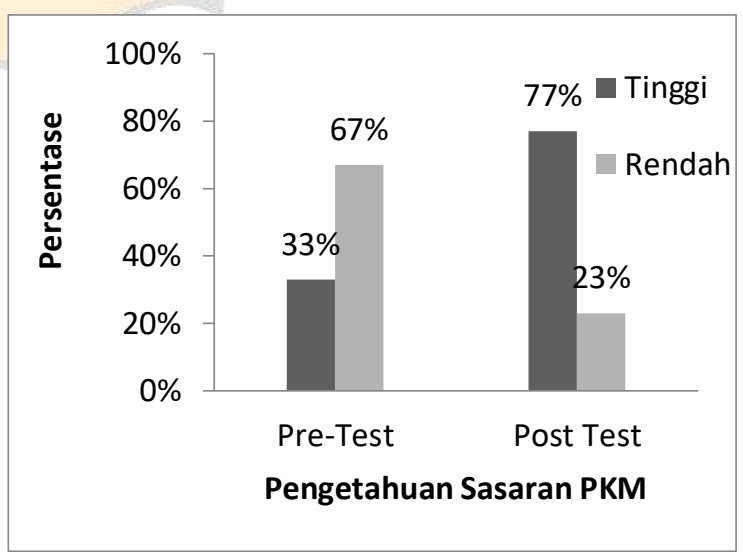

Gambar 4. Tingkat Pengetahuan Sasaran Sebelum dan Setelah Kegiatan Pengabdian Masyarakat 
Upaya kesehatan berbasis masyarakat merupakan salah satu bentuk pelayanan kesehatan di Puskesmas, termasuk upaya pembinaan kesehatan keluarga. Peran perawat komunitas di Puskesmas Paal V dapat dilakukan dengan pendekatan Progran Indonesia sehat dengan Pendekatan Keluarga (PIS-PK). Hasil dari PIS-PK salah satunya dapat mengidentifikasi penderita dengan masalah penyakit-penyakit kronis dan degeneratif seperti penyakit kardiovaskuler yang perlu dibina dan dipantau kesehatannya. Perawat dapat membantu mengidentifikasi faktor resiko penyakit kardiovaskuler dengan cara meningkatkan peran keluarga melakukan fungsi dan tugas perawatan kesehatan keluarga. Perawat dapat berperan sebagai koordinator untuk mengatur program kegiatan keperawatan keluarga untuk mempertahankan status kesehatan melalui kerjasama lintas program seperti : penyuluhan yang bekerjasama dengan program promosi kesehatan, mengkoordinir pengobatan yang teratur dan berkesinambungan pada penderita penyakit kardiovaskuler di Puskesmas Paal V. Sebagai pengawas kesehatan, perawat dapat memantau status kesehatan pasien, bekerjasama dengan program kesehatan masyarakat dan menjadikan keluarga pasien penyakit kardiovaskuler sebagai keluargaa binaan .

\section{KESIMPULAN}

Kegiatan mengabdian masyarakat dilakukan dengan pendekatan partisipatif dan sosial, metode yang digunakan adalah penyuluhan kesehatan tentang penyakit kardiovaskuler, faktor resiko penyakit kardiovaskuler pada wanita, simulasi dan demonstrasi pengisian Framingham Risk Score (FRS) untuk mengidentifikasi resiko hipertensi dalam 10 tahun ke depan dan relaksasi otot progresif untuk melatih relaksasi otot, mengatasi kelelahan, kecemasan dan memperbaiki tekanan darah.

Adanya peningkatan pengetahuan peserta setelah penyuluhan kesehatan tentang penyakit kardiovaskuler, faktor resiko penyakit kardiovaskuler pada wanita menjadi lebih baik dari 19 orang (33\%) pengetahuan tinggi menjadi 45 orang $(77 \%)$ pengetahuan tinggi.

Pada saat mendampingi peserta mengisi FRS hanya 8 orang yang pernah mampu mengisi secara lengkap sementara yang lain belum memiliki nilai HDL, sehingga tidak semua peserta mampu melengkapi form FRS. Peserta menunjukkan antusias melakukan setiap gerakan latihan relaksasi otot progresif yang diajarkan walaupun belum sepenuhnya melakukan geraan dengan benar.

\section{UCAPAN TERIMA KASIH}

Terima kasih kepada Direktur Poltekkes Kemenkes Jambi yang telah memfasilitasi izin dan pendanaan kegiatan pengabdian masyarakat ini. .

\section{DAFTAR PUSTAKA}

Inaheart, (2015). Pedoman Tatalaksana Pencegahan Penyakit V askular Bagi Perempuan. Jakarta

Kemenkes. (2014). Situasi Kesebatan Jantung. Infodatin : Jakarta

Kemenkes RI. (2014).Riset Kesehatan Dasar. Jakarta: Laporan Riskesdas. Badan Penelitian dan Pengembangan Kesehatan Kementerian Kesehatan

Kemenkes RI. (2019).Riset Kesehatan Dasar. Jakarta: Laporan Riskesdas. Badan Penelitian dan Pengembangan Kesehatan Kementerian Kesehatan

Mubarak, W.I., Chayatin, N., Santoso, B.A. (2010). Ilmu Keperawatan Komunitas Konsep dan Aplikasi, Buku 2, Jakarta: Salemba Medika

Nadianto, Fandika (2018) Hubungan Penggunaan Kontrasepsi Oral Dengan Kejadian Penyakit Jantung Koroner Di Poli Jantung Rsud Hardjono Ponorogo. Thesis : Universitas Muhammadiyah Ponorogo. Diakses tanggal 15 September 2019

Nurwidyaningtyas., (2013) Rasio EPC dan CEC sebagai prediktor disfungsi endotel pada kelompok risiko tinggi berdasarkan FRS 10 years. Jurnal Kardiologi Indonesia, 34 (I), 14 $19 . \quad$ Diperoleh dari bttp:/ / webcache.googleusercontent.com/ search. Diakses tanggal 15 September 2019

Rosjidi, C. H, Layli, I. (2014). Perempuan Lebih Rentan Terserang Kardiovaskular. Jurnal Florence VOL 7 No. 1 Januari 2014

Scottish Intercollegiate Guidelines Network. (2007). Risk estimation and the prevention of cardiovascular disease: A national clinical guideline. UK: NHS Quality Improvement 
Scotland. ISBN: 1899893997. Diperoleh dari bttp:/ / wmw.sign.ac.uk/pdf / sign97.pdf

Setiadi. AP, Halim. SV (2013). Penyakit kardiovaskuler : Seri pengobatan Rasional. Edisi Pertama. Cet. Ke-1. Yogyakarta: Graha Ilmu

Undang-Undang Nomor 12 Tahun 2012 tentang Pendidikan Tinggi (Lembaran Negara Republik Indonesia Tabun 2012 Nomor 158 